\title{
An Empirical Study of Service Quality and Customer Satisfaction of Malaysian Air Passenger
}

\section{Mohd Halim Mahphoth, Wei-Loon Koe, Ramesh Krishnan, Alia Erfani Abd Ghani and Shafinar Ismail}

Faculty of Business and Management, Universiti Teknologi MARA, Melaka City Campus, 75300 Melaka, Malaysia

\section{Abstract}

The vast majority of Malaysian air passenger have competitive choices among airlines and different service options. Customer satisfaction is what guarantees the survival of airlines and it is achievable only by matching the passengers needs with the services. Assessment of service quality and its subsequent management

Corresponding Author: Mohd Halim Mahphoth mohdhalim282@bdrmelaka .uitm.edu.my

Received: 7 August 2018 Accepted: 15 September 2018 Published: 22 October 2018

Publishing services provided by Knowledge

(c) Mohd Halim Mahphoth et al. This article is distributed under the terms of the

mons Attribution License, which permits unrestricted use and redistribution provided that the original author and source are credited.

Selection and Peer-review under the responsibility of the ICE-BEES 2018 Conference Committee

\section{G OPEN ACCESS} is of utmost importance for them to be competitive and successful in this industry. Thus, the purpose of this study was set to determine the relationship between service quality (SERVQUAL) and customer satisfaction of Malaysian air passenger. An adopted SERVQUAL instrument including five service quality constructs: empathy, tangibles, responsiveness, reliability and assurance were employed to measure the passengers perceptions about the service quality of airlines. Data were collected from 187 respondents using convenience sampling. The outcome of multiple regression analysis showed that responsiveness, reliability and assurance have a positive significant impact on customer satisfaction. However, empathy and tangible variables recorded an insignificant relationship with customer satisfaction. Conclusion and recommendation were discussed.

Keywords: service quality, customer satisfaction, air passenger

\section{Introduction}

Travel and tourism is an important economic activity and key sources of income in most countries around the world [1]. As more domestic and foreign tourist travelled abroad and low-cost carriers provided more flights on international routes, a total of 8.99 million air passenger travelled through the airports in Malaysia was recorded in December 2017, compared with 8.89 million in 2016 [2]. As the number of air passenger traffic has grown significantly in Malaysia has caused the competition in the country's airline market, therefore, each flight operator has to offer high service quality to passenger 
so as to strive for bigger market identification and survival in airline industry [3]. Thus, this research investigates service quality elements towards customer satisfaction of Malaysian air passengers.

\section{Literature Review}

Marketing literature has emphasized that every airline organization has to focus on the airline service quality in order to increase the level of passenger satisfaction [4]. Previous study has defined customer satisfaction as the service or product that meet customers' desires with the customers' evaluation on the consumption or purchases experience [5]. Moreover, the customer satisfaction level with a service or product that customer purchase is viewed based on the worth of the benefits that they received and the overall interaction of the customers with the organization which is by customers own subjective evaluation [6]. Moreover, [7] stated that the customers will have the intention to repeat purchase if only they are satisfied with the product or service.

The dimension of service quality have also been debated in the literature. For instance, [8] proposed two critical dimensions of service quality which are technical and functional. The technical refer to the tangible aspects of service delivery while functional refer to the expressive performance of the services. In contrast, [9] presented a ten dimensions including understanding the customers, tangible, access, reliability, communication, credibility, responsiveness, security, competence, and courtesy. However, after they reviewed their model, the ten dimension had been reduced to five dimension which namely, empathy, tangibles, responsiveness, reliability, and assurance, which broadly used in numerous organization and was name SERVQUAL [10]. The SERVQUAL scale has been widely applied by both academics and practitioners across industries in diverse countries [11]. It provides a comprehensive measurement scale for perceived service quality and has practical implications [12]

Not only that, [13] developed a three-component dimensional model and decided that the service environment, service product which is technical quality, and service delivery which is functional quality acted as critical dimensions in service quality. Consequently, [14] propose models of service quality elements that are focused on airline industry. On the other hand, model represented by [14] have categorized airline service quality into three aspects which are timeliness, safety, and price. 
Thus, this paper will employed [10] on service quality dimensions model SERVQUAL namely empathy, tangible, responsiveness, reliability, and assurance which constructed with customer satisfaction as illustrated in Figure 1.

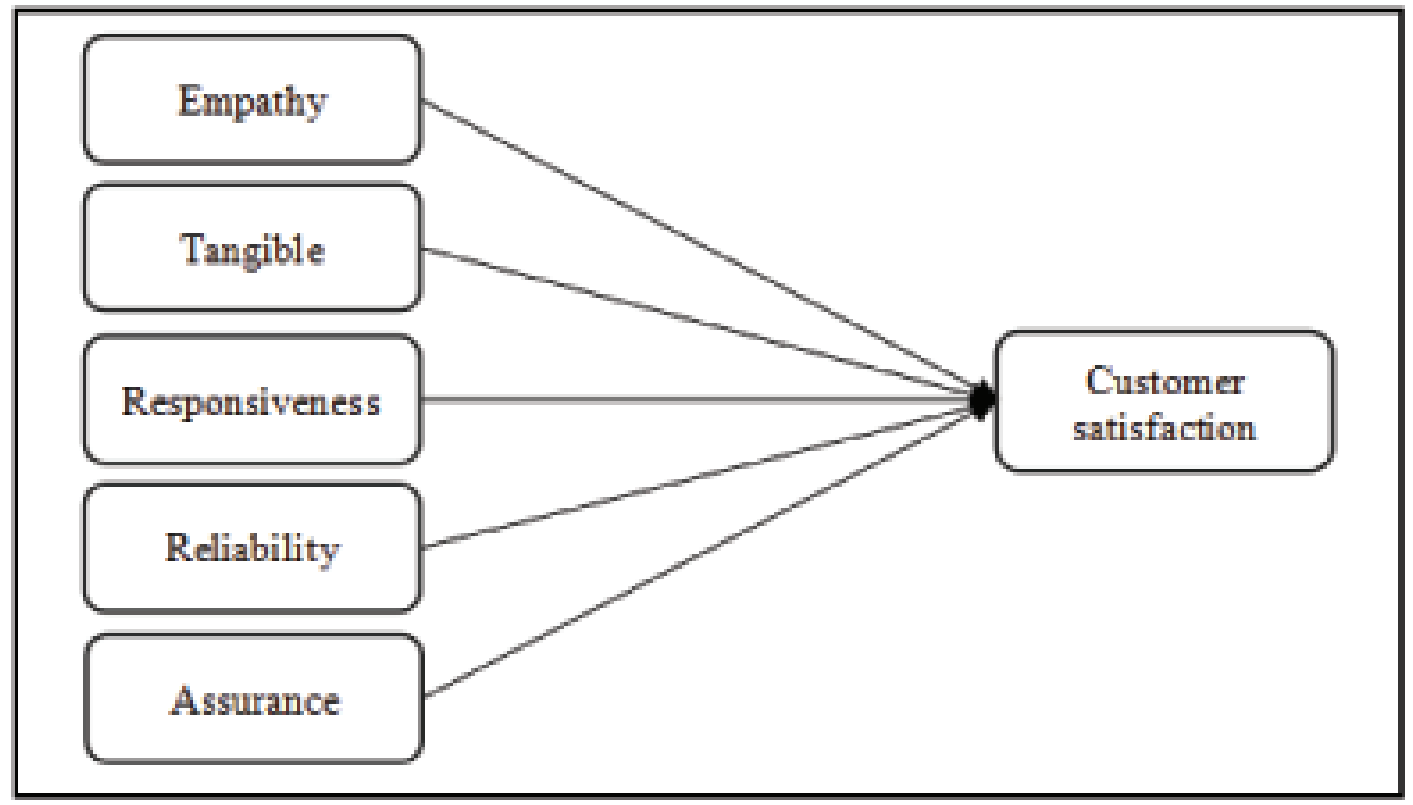

Figure 1: Theoretical framework of the study.

\section{Findings}

This section showed the result of data analyzed using quantitative method. It is divided into three major sections namely demographic profile, reliability analysis and hypothesis testing. Results of the analysis illustrated the list of findings on relationship of service quality towards customer satisfaction of Malaysian air passenger. By running the data through SPSS version 20, mean value of each of variables indicated the response of air passenger on service quality. Correlation and multiple regression analysis were used on variables in order to test the listed hypotheses.

Respondents were sampled as they were experienced using inbound and outbound of Malaysian airlines. Their feedback on each of questions recorded in questionnaire booklet. They were also engaged in respond of their views on satisfaction and service quality provided by the airlines. Thus, their data to the issues raised in the given questionnaires have credibility for analysis.

A total of 187 respondents replied the questionnaires in a complete feedback through convenient sampling. The demographic characteristics of the respondents are shown in Table 1. 


\subsection{Demographic information of air passenger}

TABLE 1: Demographic information of air passenger.

\begin{tabular}{|l|l|c|}
\hline Variables & Item(s) & $\%$ \\
\hline $\begin{array}{l}\text { Frequency using airlines from/to } \\
\text { Malaysia }\end{array}$ & $1-2$ times & 48.7 \\
\hline & $3-4$ times & 22.5 \\
\hline & $5-6$ times & 10.7 \\
\hline Purpose of using airlines & 7 times and more & 18.2 \\
\hline & Academic & 23.0 \\
\hline & Business & 5.9 \\
\hline & Holiday & 61.0 \\
\hline & Others & 10.2 \\
\hline
\end{tabular}

Numbers of air passenger were selected to response their satisfaction on service quality in the airlines. Most of the passenger were experienced from one to two times of using airlines service inbound/ outbound Malaysia (48.7\%), followed by passenger using three to four times (22.5\%) and seven times and more (18.2\%). The least respondents came from passenger using five to six times, which represented by $10.7 \%$.

Most of the air passenger (61.0\%) reported holiday as their purpose of using airlines, whereas $23.0 \%$ of the passenger responded for academic purposes. Balanced $10.2 \%$ and $5.9 \%$ of the passenger stated using airlines for others and business purposes respectively.

\subsection{Reliability analysis}

To address reliability, Cronbach's Alpha were calculated for each independent and dependant variable. This test was applied to verify consistency of variables before proceed to further analysis.

As shown in Table 2, all three variables achieved score above 0.7 for their Cronbach's Alpha with the highest value represented by Customer Satisfaction (0.90) for dependent variable and Assurance (0.86) for independent variable. This followed by Responsiveness variable results 0.85, Empathy (0.84) and Reliability (0.82). Tangible variable (0.78) was the lowest among all variables. In conclusion, all variables above were reliable and proceeded to hypothesis testing. 
TABLE 2: Reliability analysis.

Variables
Independent Variable
Empathy
Tangible
Responsiveness
Reliability
Assurance
Dependent Variable
Customer Satisfaction

\begin{tabular}{|c|}
$\begin{array}{c}\text { Realibility } \\
\text { Coefficient Alpha }\end{array}$ \\
\hline 0.84 \\
\hline 0.78 \\
\hline 0.85 \\
\hline 0.82 \\
\hline 0.86 \\
\hline
\end{tabular}

\begin{tabular}{|c|c|}
\hline Mean & $\begin{array}{c}\text { Standard } \\
\text { Deviation }\end{array}$ \\
\hline 3.69 & 0.65 \\
\hline 3.93 & 0.64 \\
\hline 3.85 & 0.61 \\
\hline 3.67 & 0.62 \\
\hline 3.88 & 0.62 \\
\hline & \\
\hline 3.99 & 0.65 \\
\hline
\end{tabular}

\subsection{Hypotheses testing}

Based on the framework of this study, five hypotheses were proposed. Each hypothesis was reiterated below and then the result of statistical analysis for testing them were reported. All hypotheses were tested by using correlation analysis and multiple linear regression analysis.

\subsection{Correlation analysis}

A correlation coefficient measured the strength of a linear between two variables. In this study, a Pearson correlation coefficient measured the strength of a linear between the Customer Satisfaction and five service quality dimensions (Empathy, Tangible, Responsiveness, Reliability and Assurance). From Table 3, the correlation between overall independent and dependant variables were positive and significant at 0.01 level (2-tailed), with all values represented in between of 0.6 to 0.8 , which means moderately strong association. The highest association represented by Assurance, the correlation was 0.741 ( $p=0.000)$ followed by Responsiveness $(r=0.710, p=0.000)$ and Reliability ( $r=0.701, \rho=0.000$ ). Tangible and Empathy resulted $r$ value below 0.7 , with value $(r=0.633, p=0.000)$ and $(r=0.627, p=0.000)$ respectively. Therefore, the study indicated that there were associations among service quality dimensions and customer satisfaction of Malaysian air passenger. 
TABLE 3: Correlation among service quality dimensions and customer satisfaction of Malaysian air passenger.

\begin{tabular}{l|c|}
\hline Service Quality & $\begin{array}{c}\text { Customer } \\
\text { Satisfaction }\end{array}$ \\
\hline Dimensions & $0.627^{\star *}$ \\
\hline Empathy & $0.633^{\star *}$ \\
\hline Tangible & $0.710^{* *}$ \\
\hline Responsiveness & $0.701^{\star *}$ \\
\hline Reliability & $0.741^{\star *}$ \\
\hline Assurance &
\end{tabular}

\subsection{Multiple Linear Regression Analysis}

Multiple linear regression analysis is a statistical analysis that used to examine relationship between independent variables and a dependent variable. There were five hypotheses tested, namely;

H1: There is a relationship between empathy towards customer satisfaction of Malaysian air passenger.

H2: There is a relationship between tangible towards customer satisfaction of Malaysian air passenger.

H3: There is a relationship between responsiveness towards customer satisfaction of Malaysian air passenger.

H4: There is a relationship between reliability towards customer satisfaction of Malaysian air passenger.

H5: There is a relationship between assurance towards customer satisfaction of Malaysian air passenger.

In this standard multiple linear regression analysis, enter method was applied to test relationship between Customer Satisfaction, which is considered as aggregated variable when Empathy, Tangible, Responsiveness, Reliability and Assurance act as independent variables. As a result in Table 4, the independent variables (Empathy, Tangible, Responsiveness, Reliability and Assurance) explained $63.6 \%$ of the total variances in the dependent variable (Customer Satisfaction) with R-Square 0.636. Thus, the relationship between Service Quality Dimensions towards Customer Satisfaction was strong. 
TABLE 4: Relationship between service quality dimensions towards customer satisfaction of Malaysian air passenger.

\begin{tabular}{l|c|c|c|}
\hline Dimensions & B & Beta & Sig. \\
\hline Empathy & 0.114 & 0.114 & 0.085 \\
\hline Tangible & 0.106 & 0.105 & 0.117 \\
\hline Responsiveness & 0.200 & 0.190 & $0.019^{*}$ \\
\hline Reliability & 0.173 & 0.165 & $0.036^{*}$ \\
\hline Assurance & 0.347 & 0.334 & $0.000^{* *}$ \\
\hline R-Square & 0.636 & & \\
\hline R-Square & 0.636 & & $*$ significant \\
\hline Adjusted R-Square & 0.626 & & P $<0.010$ \\
\hline Method: Enter & & & $*$ significant \\
\hline & & & P $<0.050$
\end{tabular}

Three dimensions emerged as significant factors in explaining the Customer Satisfaction with Assurance received p-value of 0.000 reported as highly, positively and significantly related to the dependant variable at $1 \%$ level of significant. The other significant factors were Responsiveness and Reliability which showed significant at $5 \%$ level of significant. However, Empathy and Tangible showed insignificant towards customer satisfaction. Thus, this findings fail to reject $\mathrm{H}_{3}, \mathrm{H}_{4}$ and $\mathrm{H}_{5}$ of the study. Otherwise, $\mathrm{H}_{1}$ and $\mathrm{H}_{2}$ were rejected.

\section{Conclusion and Recommendation}

Based on the study, it can be concluded that there are three independent variables had relationship with customer satisfaction of air passengers which are responsiveness, reliability, and assurance. The other independent variables which are empathy and tangible have no significant relationship with satisfaction of air passengers.

As for recommendation, firstly, employee's skills need to be enhanced. Airline operators are responsible in deciding what type of training need to be given to their employees. By this way, employers know they have responsibility for providing quality in their service, no matter their role in the company. Furthermore, all of the employees should involve in service quality seminar, online, or in person, as a part of a performance improvement requirement. Besides, employers should organize training sessions that target specific issue such as how to interact with the passengers in the flight or at the counter. For instance, training session can be targeted on the service improvement during the operations, like the flight attendant should be polite, act quick and prompt service, always smile to customer, and have knowledge. Not only that, 
they have to train employees to see the connection between their actions and, more broadly, their work ethic, and the airline's overall performance.

Secondly, airlines should improve the quality of food and beverage that is served to air passengers. The food should be properly prepared and the service should be prompt and courteous. The food and beverages should fulfil the specifications. This is because the customer expects the food to be what is promised on the menu, to be cooked and prepared properly, to be clean and to have the correct flavour. This is considered as quality food. Therefore, it is a good quality of food and beverage if it is consistent with what is advertised.

Thirdly, the airlines should constantly measure, monitor and improve their in-flight entertainment. Service quality can be improved if they take passenger enjoyment seriously. Passengers will enjoy if the in-flight entertainment is improved. For instances, airlines should provide more regional and international movies, famous TV shows, video games, music, and magazine to suit every mood and taste. The movies, TV shows, music, and magazine should be covered from all genre because every customer have their own taste and preferences. This will directly increase passengers' satisfaction as they can choose what they favour the most. Besides, passengers can play a variety of games and even linking up with other customers in the same flight. Additionally, the airlines should improve the in-flight entertainment by providing new streaming in-flight entertainment (Wi-Fi). This is for customers who favours to watch movies, listen to music, or play games through their own smartphone, tablet or laptop. This in-flight entertainment is a very important especially for a long haul flight.

By this way, airlines can gaining consumer, retaining consumer, and gaining profit. By having a high quality in-flight entertainment, it make the airline more desirable. Thus, this will help bring in new passengers and retain the existing passengers as the level of satisfaction increase due to high quality of services.

\section{Acknowledgments}

The authors would like to thank the management of Universiti Teknologi MARA, Melaka City Campus for their support in making this project possible. 


\section{References}

[1] World Travel and Tourism Council (WTTC). (2017). Travel and Tourism: Global Economic Impact and Issues, 2017. Retrieved 14 July, 2018, from https://www.wttc. org/-/media/files/reports/economic-impact...2017/world2017.pdf

[2] Theedgemarketscom. (2017), Theedgemarketscom. Retrieved 14 July, 2018, from http://www.theedgemarkets.com/article/malaysian-air-passenger-traffic4-march-says-mahb

[3] Wang, R., Lin, Y. H., \& Tseng, M. L. (2011). Evaluation of Customer Perceptions On Airline Service Quality in Uncertainty. Procedia-Social and Behavioral Sciences, vol. 25, pp. 419-437.

[4] Kalaiarasan, K., Appannan, S., \& Doraisamy, B. (2015). A Study on Service Quality on Customer Satisfaction in Low Cost Airline Industries. International Journal of Science, Environment and Technology, vol. 4, no. 4, pp. 1126-1138.

[5] Chen, Y. H., Tseng, M. L., \& Lin, R. J. (2011). Evaluating The Customer Perceptions on In-Flight Service Quality. African Journal of Business Management, vol. 5, no. 7, pp. 2854-2864.

[6] Szczepańska, K., \& Gawron, P. (2011). Loyalty Programs Effectiveness. Foundations of Management, vol. 3, no.2, pp. 89-102.

[7] Zekiri, J. (2011). Applying Servqual Model And Factor Analysis in Assessing Customer Satisfaction with Service Quality: The Case of Mobile Telecommunications in Macedonia. International Bulletin of Business Administration, vol.11, pp. 86-101.

[8] Grönroos, C. (1982). An Applied Service Marketing Theory. European Journal of Marketing, vol. 16, no.7, pp. 30-41.

[9] Parasuraman, A., Zeithaml, V. A., \& Berry, L. L. (1985). A Conceptual Model of Service Quality And Its Implications For Future Research. The Journal of Marketing, pp. 41-50.

[10] Parasuraman, A., Zeithaml, V. A., \& Berry, L. L. (1988). SERVQUAL: A MultipleItem Scale for Measuring Consumer Perceptions of Service Quality. Journal of Retailing, vol. 64, no. 1, pp. 12.

[11] Ali, F., Khan, A. S., \& Rehman, F. A. M. S. (2012). An Assessment of The Service Quality Using Gap Analysis: A Study Conducted at Chitral, Pakistan. Interdisciplinary Journal of Contemporary Research In Business, vol. 4, no. 3, pp. 259-266.

[12] Rust, R. T., \& Verhoef, P. C. (2005). Optimizing The Marketing Interventions Mix in Intermediate-Term CRM. Marketing Science, vol. 24, no. 3, 477-489. 
[13] Oliver, R. L. (1994). Conceptual Issues in The Structural Analysis of Consumption Emotion, Satisfaction, and Quality: Evidence in a Service Setting. Advances in Consumer Research, Vol. 21, pp. 16-22.

[14] Gourdin, K. N. (1988). Bringing Quality Back to Commercial Air Travel. Transportation Journal, pp. $23-29$. 